Research Article

\title{
GIS-Enabled Culvert Design: A Case Study in Tuscaloosa, Alabama
}

\author{
Ashton D. Greer (D), Zachary B. Wilbanks, Leah D. Clifton, Bradford Wilson, \\ and Andrew J. Graettinger \\ Department of Civil, Construction, and Environmental Engineering, The University of Alabama, Tuscaloosa, AL 35401, USA \\ Correspondence should be addressed to Ashton D. Greer; adgreer@crimson.ua.edu
}

Received 28 February 2018; Accepted 29 July 2018; Published 19 September 2018

Academic Editor: Kirk Hatfield

Copyright (c) 2018 Ashton D. Greer et al. This is an open access article distributed under the Creative Commons Attribution License, which permits unrestricted use, distribution, and reproduction in any medium, provided the original work is properly cited.

\begin{abstract}
A GIS-enabled culvert design module is presented. This module employs Python programming to combine a proposed culvert location, topography, land use, and rainfall data to automatically design a culvert. The module is embedded within ESRI ArcGIS 10.4 software, providing a seamless single platform that eliminates error propagation associated with cross-platform data transfer as well as providing 95\% time savings over traditional calculation methods. The module uses United States Geological Survey digital elevation data to analyze watershed topography. Runoff coefficients are determined from data available through the National Land Cover Database. Rainfall data are retrieved from the National Oceanic and Atmospheric Administration and combined with watershed and land use information to calculate peak discharge using the rational method. Peak discharge is then combined with culvert design parameters to design a single-barrel culvert. The module was used to redesign ten existing culverts along a highway in Tuscaloosa, Alabama, resulting in designs for updated land cover and rainfall conditions. Results from the techniques developed herein can be used for planning purposes and to highlight vulnerabilities in the existing infrastructure. The automation methods may be extended to other hydrologic objectives and runoff mitigation design such as open-channel design and detention or retention ponds.
\end{abstract}

\section{Introduction}

Culverts are an integral part of the built environment, particularly within transportation networks. They are the most prevalent means of conveying water from one side of a roadway to another, with the number of culverts in each state ranging from tens of thousands to hundreds of thousands [1]. Maintenance of culverts is frequently neglected in favor of highway infrastructure such as pavements or bridges, and culverts are becoming increasingly vulnerable to deterioration as they age. The quantity of culverts along roadways produces a burden on the agencies that design, manage, and maintain this infrastructure, and thus there is a need to efficiently design and analyze these systems.

Conventional culvert design software programs include governmental software programs such as the Federal Highway Administration (FHWA) Culvert Hydraulic
Analysis Program (HY-8) [2] or commercial programs such as Bentley CulvertMaster [3]. Design parameters for $\mathrm{cy}$ lindrical culverts include the peak flowrate, slope of the culvert, headwater and tailwater elevations, and the diameter of a culvert barrel [4]. Typical culvert design software automatically calculates and adjusts site-specific parameters like culvert slope and headwater elevations until suitable design conditions are met. However, peak flowrate, which is a critical input for many different types of hydraulic infrastructure, must often be performed externally, then translated and formatted before the data can be used. Hydrological analysis can be time consuming if performed by hand, and data transfer often leads to errors due to translation and formatting. Therefore, these hydrological analyses must be performed externally, through either hydrologic modeling software, a geographic information system (GIS), or a combination of the two. 
Common hydrological models include WinTR-20 and WinTR-55 [5], HEC-HMS [6], and others. Most hydrological models have evolved independently of GIS. Therefore, using a GIS with these models requires an interface program that translates, formats, and exchanges information between a GIS and a model. Although these translation frameworks can employ off-the-shelf hydrologic models and GISs, they can often require licensing and expertise with multiple programs and an interface program that can be prone to errors due to the import and export of data. An alternative framework is "embedded coupling," in which a hydrological analysis is accomplished with added functions within a GIS [7]. Modern GIS platforms have many tools and functions that are needed for a hydrologic analysis. Embedded coupling of a hydrologic model eliminates the need to maintain multiple programs and removes the problems associated with interplatform data transfer. Despite the apparent advantages to embed hydrologic analysis tools within a GIS, most efforts to date have been of the interface type. Additionally, although GIS has been used to perform hydrologic analyses and certain hydraulic designs like stormwater systems [8-13], it has not been used to produce a culvert design completely within the platform.

This paper describes a GIS-enabled technique to allow users to produce a single-barrel, circular, concrete culvert design at a specific location completely within a GIS platform. The culvert design module runs from a single mouse click on a map at a culvert location within the GIS software and produces all of the required parameters associated with a complete design. The culvert module utilizes existing ArcGIS [14] tools and custom code and is completely contained within ArcGIS. There are disadvantages to ArcGIS, including that it is costly and ArcGIS tools can require updates as new versions of ArcGIS are developed. However, ArcGIS is already widely used by practitioners who perform similar types of work, and the tool will be updated as needed. The functionality of the tool is demonstrated by redesigning ten existing culverts along Highway 43 in Tuscaloosa, Alabama, using updated land cover and rainfall data. This all-inclusive tool produces significant time savings as well as eliminates the need to export and exchange data with other hydrological-analysis programs. Results from the techniques developed herein can be used for planning purposes and to highlight vulnerabilities in existing infrastructure. In addition, the techniques displayed throughout this paper may be extended to other hydrological objectives such as openchannel design and runoff mitigation designs such as detention and retention ponds.

\section{Materials and Methods}

The procedures automated by the culvert design tool can be divided into two main phases: peak flow determination and culvert design. These phases are accomplished by synthesizing ArcGIS procedures in a manner that allows the output from one procedure to be sequentially provided as input to the next procedure, as shown in Figure 1. The tool is developed as a Python Add-in, which is a Python-programmed customization such as a tool or toolbar that plugs into
ArcMap to provide additional functionality [15]. The peak flow determination phase of the process is programmed using ArcPy, a Python site package that allows a user to perform geoprocessing and Spatial Analyst operations with Python. The outputs of these operations within ArcPy are sequentially connected and incorporated into other operations.

To activate the tool within an ArcMap session, the user clicks on a button to begin the tool, which will transform the curser into a crosshair. The crosshair cursor can then be used to select the desired culvert location. Clicking on the culvert location will prompt the input dialog box to open (Figure 2). Within the dialog box, the user will be prompted to provide input parameters for the desired culvert, and these parameters are then defined as variables to be used in sequential calculations for a culvert at that location.

First, the user must download and identify two distinct data sets. Then, a digital elevation model (DEM) is required. A DEM can be downloaded from the US Geographical Survey (USGS) 3D Elevation Program (3DEP) for most of the conterminous US [16]. The most common DEM resolution through the $3 \mathrm{DEP}$ is a 10 -meter raster. While the $3 \mathrm{DEP}$ is a common source of DEMs, errors can sometimes be present, so users may utilize DEMs from other sources if they wish. The second required data set is a land cover raster, which can be obtained at a 30-meter resolution from the National Land Cover Dataset (NLCD) [17].

Site-specific design parameters include culvert length, slope, headwater, tailwater, and design storm average recurrence interval (ARI). Culvert length $(L)$ is the horizontal distance from the inlet of the culvert to the outlet. This is often governed by the width of the roadway or embankment. Culvert slope $(s)$ is the difference in the outlet elevation versus the inlet elevation, divided by the culvert length. The slope is typically governed by the natural slope of the stream channel. Headwater $\left(H_{\mathrm{w}}\right)$ depth is the maximum allowable height of water at the inlet of the culvert. Headwater is determined based on the elevation of the roadway or embankment and the difference between the roadway surface and stream surface. Tailwater $\left(T_{\mathrm{w}}\right)$ depth is the height of water at the outlet of the culvert. Tailwater can be calculated externally using Manning's equation for stream depth within a channel if channel characteristics are known. Alternatively, it can be conservatively assumed to be the maximum allowable depth of water based on roadway elevation, similarly to $H_{\mathrm{w}}$. Design storm ARI is an estimate of the likelihood of a certain storm occurring. The user can select from a dropdown list of several commonly used design storms (25-year storm, 50-year storm, etc.). Once all of the input parameters have been defined, the user will click on the "Calculate Culvert Design" button, and ArcMap will begin a series of automated processes.

2.1. Peak Flowrate Determination. The first step in designing a culvert is determining a design peak flowrate, which is the maximum flow of water that the culvert will be required to convey. There are numerous lumped-parameter approaches to estimating peak flowrates in urban areas including 


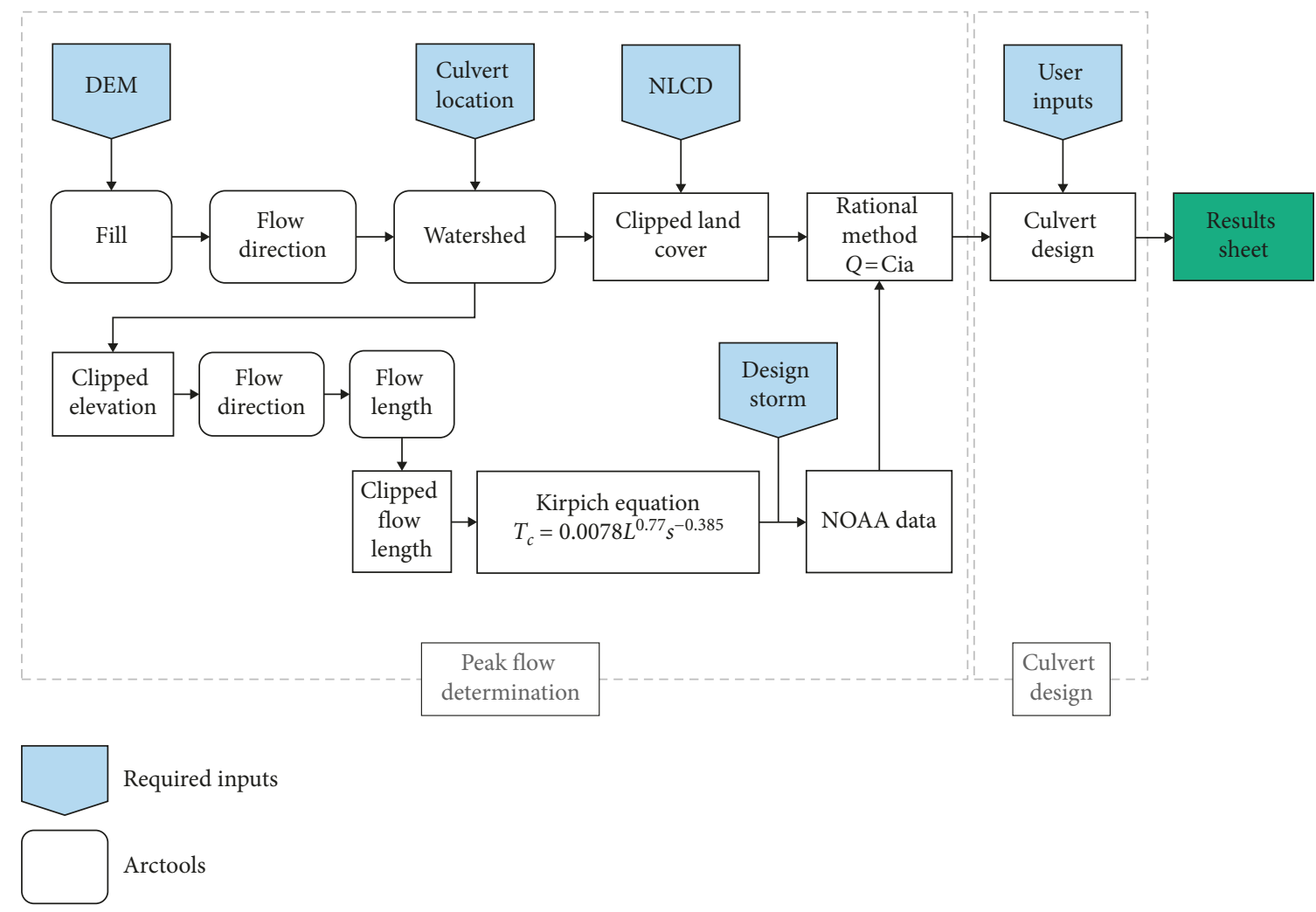

FIGURE 1: Flowchart illustrating automation and necessary components.

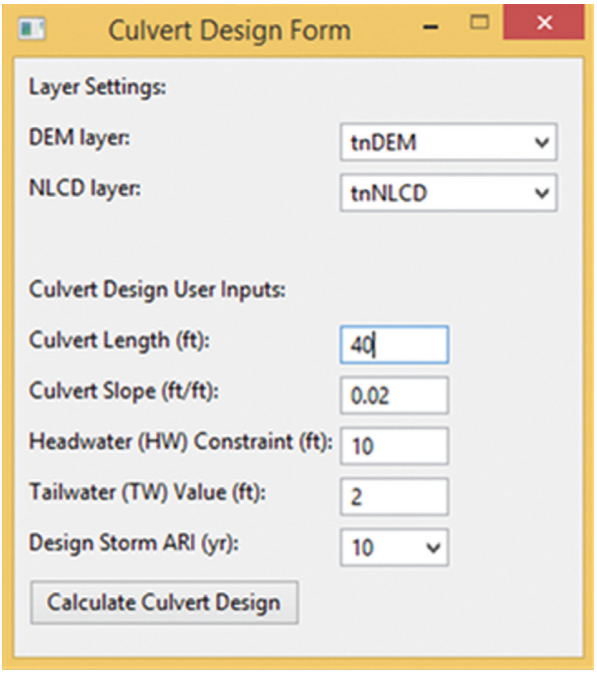

FIGURE 2: Culvert design user interface form.

regression, TR-55, and the rational method. There are also numerous software programs that incorporate these approaches. For example, USGS StreamStats is a GIS-based web interface that can be used to delineate drainage areas for sites on streams and then get basin characteristics and flow estimations based on regression techniques [18]. WinTR-55 and Forest Service Peak Flow Calculator [19] are both freely available computer models that use TR-55 [20] Curve Number methods to analyze small watersheds. While there are benefits and limitations to each of these models, and each could feasibility be integrated into the tool herein, the rational method was chosen as the peak flowrate approach for this work because of its widespread use. The rational method, which was introduced to the United States in 1889, is still the most commonly used method for designing drainage infrastructure in watersheds smaller than 200 acres [21]. The rational method requires drainage basin characteristics of the watershed up-gradient from the location of a hydraulic structure being designed. While simple, it is often an appropriate method of calculating peak flow for planning purposes as the required inputs are often widely available.

2.1.1. Rational Method Parameters. As shown in Equation (1), $Q$ is the flowrate in $\mathrm{m}^{3} / \mathrm{s}, C$ is the dimensionless rational method runoff coefficient, $i$ is the rainfall intensity in $\mathrm{mm} / \mathrm{hr}$ for a storm duration equal to $T_{c}$, and $A$ is the watershed area in ha:

$$
Q=0.278 C i A \text {. }
$$

The culvert tool also incorporates a frequency factor to account for antecedent moisture conditions for large storm events. These factors are programmatically included in the code to result in Equation (2), where $C_{\mathrm{f}}$ is the multiplier, as shown in Table 1:

$$
Q=0.278 C C_{\mathrm{f}} i A .
$$

This work employs GIS to determine each of these variables by analyzing widely available elevation, land cover, and precipitation data sets. 
TABle 1: Frequency factors for the rational method.

\begin{tabular}{lc}
\hline Design storm (years) & Multiplier, $C_{\mathrm{f}}$ \\
\hline $1-10$ & 1 \\
25 & 1.1 \\
50 & 1.2 \\
$100-1000$ & 1.25 \\
\hline
\end{tabular}

2.1.2. Watershed Delineation. Determining watershed area involves analyzing topographical data. A DEM raster provides the input landscape data required to delineate a basin. DEMs are often littered with "sinks" and "spikes," erroneous pixels of low or high elevation values that appear in the data set during automated raster development. Default creation of a depressionless DEM by the ArcMap Fill tool corrects most sinks (Figure 3(a)).

The depressionless DEM is ready to be used as input to the Flow Direction tool to calculate a cell-by-cell flow direction raster, showing the steepest descent from one raster cell to a neighboring cell (Figure 3(b)). From the flow direction raster, the ArcMap Flow Accumulation tool sums cell-by-cell flow directions in a downstream direction to define flow paths from contiguous cells of greatest upstream source (tributary) cells. The flow direction output raster also serves as input to the ArcMap Flow Length tool, from which the length of flow paths upstream or downstream of a given point can be calculated.

The user-selected culvert location and flow accumulation output raster are both inputs to the ArcMap Snap Pour Point tool, which snaps the culvert to the cell of greatest flow accumulation within a specified distance of 30 meters to ensure that the culvert location lands on a GIS-derived stream flow path. A flow accumulation raster, together with a snapped culvert location, is sufficient to define a boundary of a watershed that feeds a culvert. The ArcMap Watershed tool is employed to define the watershed boundary (Figure 3(c)).

The output watershed raster is used with the ArcMap Raster Clip tool to clip the elevation, flow length, and land cover rasters to the extent relevant to a culvert. Clipped elevation and flow length outputs provide the design parameters (flow length and slope) for the time of concentration $\left(T_{\mathrm{c}}\right)$ calculation. The area is calculated by multiplying the total number of cells, or pixels, from the clipped land use raster by the area of each cell, which for the NLCD is 30 by 30 meters. The output watershed raster serves as a clip template for the land cover data.

It is important to note that there are limitations to using DEMs to delineate urban watersheds. Ten meter DEMs often do not account for man-made features such as storm drains or below-ground infrastructures that reroute water through a landscape. However, traditional methods of delineating watersheds often involve analyzing elevation contours through either manual or digital techniques and are also vulnerable to these same limitations. Figure 4 visually demonstrates the similarities between the drainage basins for three separate Tuscaloosa culverts delineated (a) manually and (b) by utilizing a 10-meter DEM. It is of note that high-resolution DEMs obtained through technology such as LiDAR are becoming more widely available and should provide additional accuracy to this methodology.

2.1.3. Land Cover Determination. The clipped watershed land cover raster is produced by using the ArcMap Raster Clip function available within the Spatial Analyst toolbox. The clipped land cover raster is used to determine the rational method coefficient value, $C$, for an entire watershed. Each raster cell corresponds to a particular land cover class that can be assigned a $C$ value. Table 2 shows a relationship between NLCD land cover classes and $C$ values. The relationship between land cover class and $C$ values was conservatively determined by identifying accepted $C$ values throughout the common hydrology literature [22]. An overall weighted average $C$ value can then be calculated for an entire watershed. The clipped land cover raster is used to calculate the overall weighted $C$ by the following equation:

$$
C=\frac{\sum_{j=1}^{n}\left(C_{j} * A_{j}\right)}{\sum_{j=1}^{n} A_{j}},
$$

where $A_{j}$ is the area for land cover $j$ and $n$ is the number of distinct land cover categories.

2.1.4. Rainfall Intensity Calculation. Rainfall intensity (i) is a meteorological parameter based on location, but at a coarser scale than a location along a flow path or even the scale of a single watershed. Design rainfall intensity is governed by climate as well as watershed surface characteristics. The underlying assumption of the rational method is that peak flow occurs when runoff from the most hydrologically distant point within the watershed has reached the culvert location. The time at which this occurs is called the time of concentration $\left(T_{c}\right)$. The rational method often employs the time of concentration as a measure of storm duration when calculating rainfall intensity $(i)$.

The snapped culvert location, in combination with the flow direction output, provides input for the ArcMap Flow Length tool to calculate the longest upslope flow path from the culvert or pour point. The Kirpich equation, shown in Equation (4), is employed to calculate the $T_{c}$ upstream of a culvert location. As shown in Equation (4), $T_{c}$ is the time of concentration, $L$ is the length of the channel from the culvert location to headwater location in meters, and $S$ is the average watershed slope in rise over run:

$$
T_{\mathrm{c}}=0.0078 L^{0.77} S^{-0.385} \text {. }
$$

The Kirpich equation was empirically developed in rural Tennessee basins and should be limited to watersheds with drainage areas of less than $0.8 \mathrm{~km}^{2}$ (200 acres) and flow lengths of less than 3,048 meters (10,000 feet) [23]. Though 


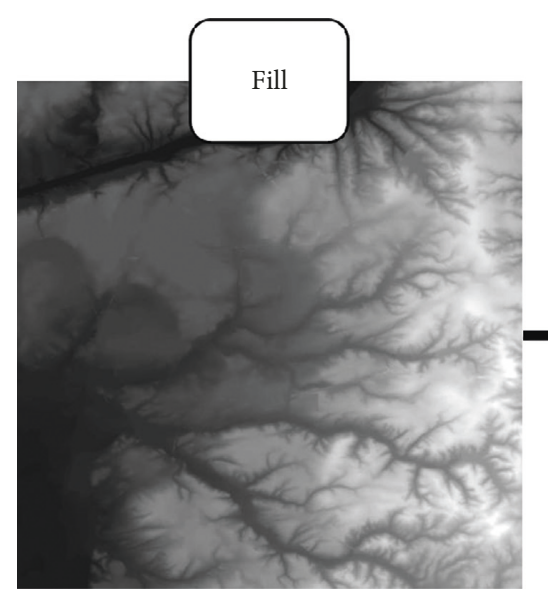

(a)

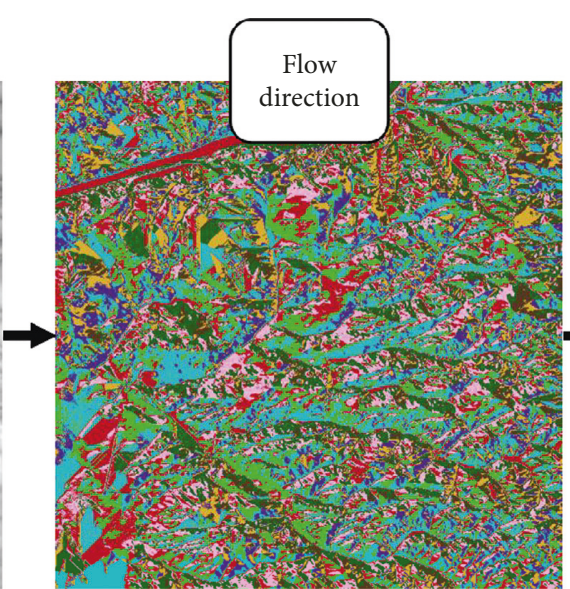

(b)

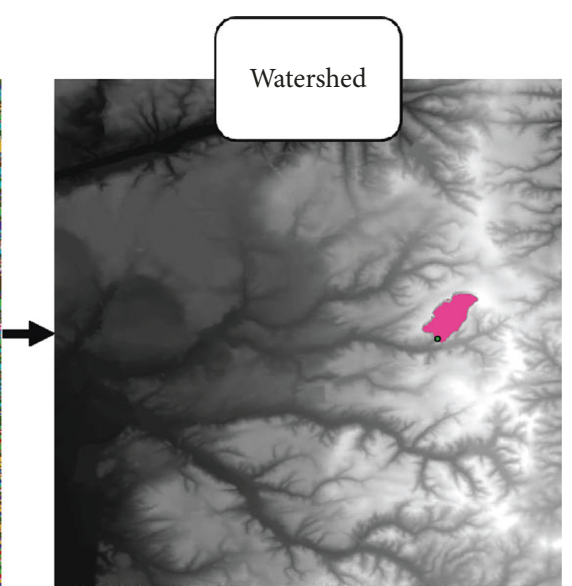

(c)

Figure 3: Progression of watershed delineation outputs: (a) fill, (b) flow direction, and (c) delineated watershed polygon.

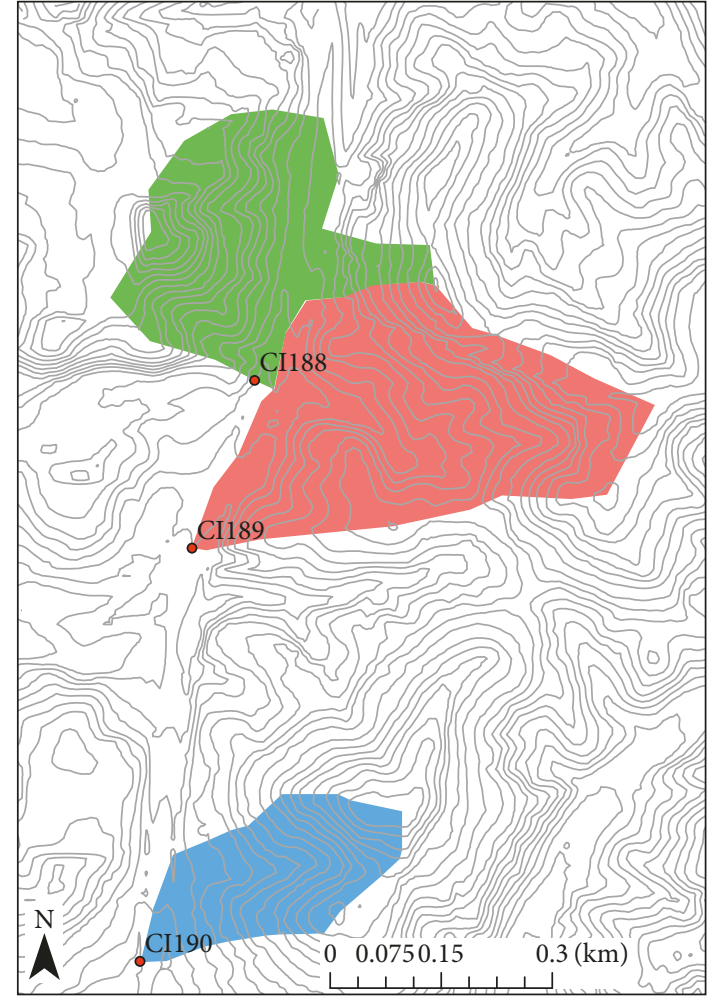

CI188 watershed CI189 watershed CI190 watershed

- Culvert location

2-meter contour
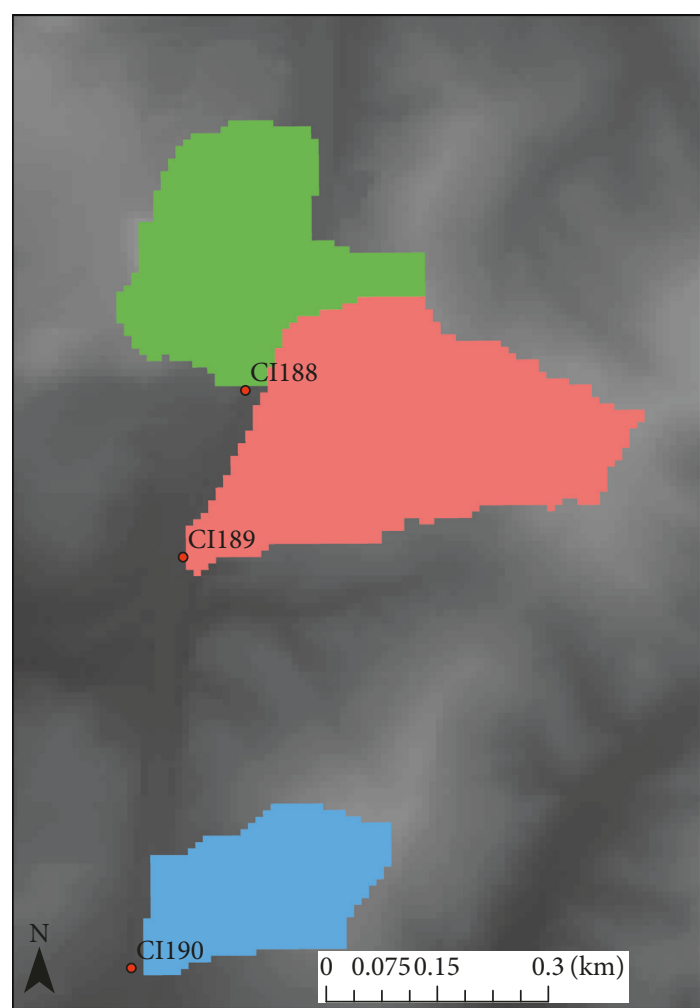

CI188 watershed CI189 watershed
Elevation (m)

- High: 202.185

(a)

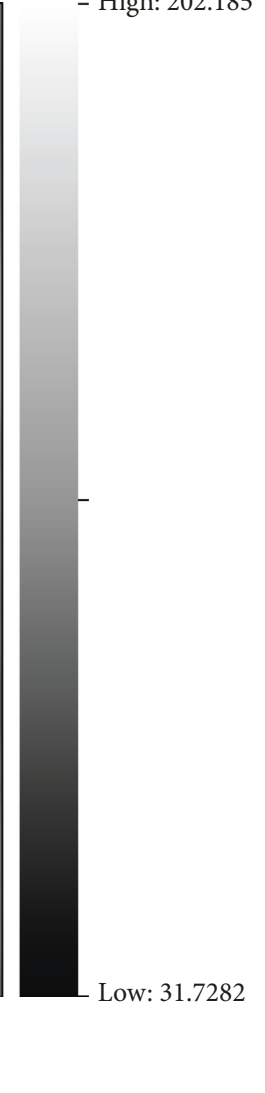

(b)

Figure 4: Three Tuscaloosa culvert drainage basins delineated (a) by hand through use of a contour map and (b) through raster-based methods using a 10 -meter DEM.

limited, the Kirpich equation provides very conservative short times of concentration that result in high peak flowrates from the rational method. The depressionless DEM (previously calculated), together with $L$, provides the average slope along the previously calculated flow accumulation path, for the final input required for the Kirpich equation.

On the National Oceanic and Atmospheric Administration (NOAA) website is a link to the Precipitation 
TABLE 2: Land use attributes and associated $C$ values.

\begin{tabular}{lcc}
\hline NLCD value & Land cover class & $C$ value \\
\hline 11 & Open water & 1 \\
21 & Developed, open space & 0.8 \\
22 & Developed, low intensity & 0.85 \\
23 & Developed, medium intensity & 0.9 \\
24 & Developed, high intensity & 0.95 \\
31 & Barren land & 0.6 \\
41 & Deciduous forest & 0.3 \\
42 & Evergreen forest & 0.2 \\
43 & Mixed forest & 0.25 \\
52 & Shrub/scrub & 0.7 \\
71 & Herbaceous & 0.65 \\
81 & Hay/pasture & 0.4 \\
82 & Cultivated crops & 0.45 \\
90 & Woody wetlands & 0.9 \\
95 & Emergent herbaceous wetlands & 0.95 \\
\hline
\end{tabular}

Frequency Data Server (PFDS), a database site that allows users to obtain the most recent rainfall information available in certain states [24]. The online intensity data from the NOAA PFDS can be used to determine an intensity value for the rational method if the watershed $T_{c}$ is known. With the location of the culvert (latitude and longitude), the design storm ARI of choice, and the $T_{c}$, the intensity can be determined from the data using linear interpolation between available storm duration data. All of these inputs are automatically retrieved and determined in the overall culvert design process and, in turn, are used to determine the appropriate $i$ value from the online NOAA PFDS. Finally, the design flowrate is calculated using the rational method equation and used for the final culvert design phase.

2.2. Culvert Design. The culvert design method employed in this work is based on procedures outlined by the FHWA [25]. However, because the typical FHWA design method for culverts involves the use of charts, the process was modified to use culvert design equations available through the FHWA. Other culvert design programs are able to evaluate a variety of flow types and configurations, but for simplicity, the only culvert design method demonstrated herein is a single-barrel circular concrete pipe with projecting inlet and outlet. This culvert also has a submerged inlet with larger headwater buildups at the culvert inlet location. Equation (5) is empirical equations that need to be satisfied for the concrete pipe culvert described previously. In Equation (5), $Q$ is the design flowrate, $A$ is the crosssectional area of the culvert, $g$ is the acceleration due to gravity, $D$ is the diameter of the culvert, $S_{\mathrm{o}}$ is the slope of the culvert in rise over run, $R$ is the hydraulic radius, $n$ is Manning's coefficient, $L$ is the length of the culvert, $V$ is the velocity of the flow, $M$ is a constant of 1.00 for SI units (1.49 for Imperial units), $H_{\mathrm{w}}$ is the headwater height, $T_{\mathrm{w}}$ is the tailwater height, and $Y, C$, and $K$ values are constants for circular concrete pipes. For this work, $Y$ is assumed to have a value of $0.69, K_{\mathrm{e}}$ is $0.2, K_{\mathrm{s}}$ is -0.5 , and $K_{\mathrm{n}}$ is 1.49 .

$$
\begin{aligned}
\frac{Q}{A D^{0.5} g^{0.5}} \geq & 0.70 \text { (submerged) } \\
\frac{H_{\mathrm{w}}}{D}= & C\left(\frac{\mathrm{Q}}{A \sqrt{g D}}\right)^{2}+Y+K_{\mathrm{s}} S_{\mathrm{o}} \text { (inlet control) } \\
H_{\mathrm{w}}= & T_{\mathrm{w}}-S_{\mathrm{o}} L+\left(1+K_{\mathrm{e}}+\frac{2 g n^{2} L}{K_{n}^{2} R^{(4 / 3)}}\right) \\
& \cdot \frac{Q^{2}}{2 g A^{2}}(\text { outlet control) } \\
V= & \frac{M}{n} R^{2 / 3} S_{\mathrm{o}}^{1 / 2} \text { (flow velocity) }
\end{aligned}
$$

The design flowrate is taken as the peak flowrate calculated previously. The peak flowrate and the other userdefined input values are put into the empirical design equations, and the smallest possible value for diameter is then input into the equations. The inlet and outlet headwater conditions are checked for control. The culvert diameter is iteratively increased until a culvert design successfully produces a $H_{\mathrm{w}}$ value smaller than the user input headwater constraint, thus resulting in the selection of a conservative culvert diameter. Submergence and flow velocity are calculated and compared to acceptable values to ensure that the design is valid.

Once the design process has completed execution, a plan sheet displaying the design results is generated and displayed to the user, as shown in Figure 5. The plan sheet includes a profile and cross-sectional view of a circular concrete culvert, with dimensions specific to the culvert being designed. In addition, the sheet provides the location of the culvert on a map as well as a brief cost estimate summary.

2.3. Testing and Verification. The automated culvert design procedure discussed throughout this work was verified with traditional hand calculations and other available software for three randomly selected locations. This provided quality assurance and control for the tool. The hand-calculated parameters were obtained by digitizing watershed basins in computer-aided design software from elevation contours on USGS quadrangle maps. A Google aerial image was overlaid to provide land cover information that was used to obtain the rational method coefficient, $C$. The length and slope of the flow channel for the Kirpich equation were calculated by digitizing the longest hydrologic flow path and analyzing the elevation contours to determine the slope along the flow path. Once the $T_{\mathrm{c}}$ was calculated along with a chosen design storm of a 10-year event, $i$ was retrieved from the online NOAA PFDS. The hand calculation procedure discussed in this section is the typical approach employed to determine a design flowrate for hydraulic structure through the rational method.

The flowrates were calculated for each culvert locations and compared to the GIS-enabled automated approach presented in the project. Table 3 illustrates the results from 


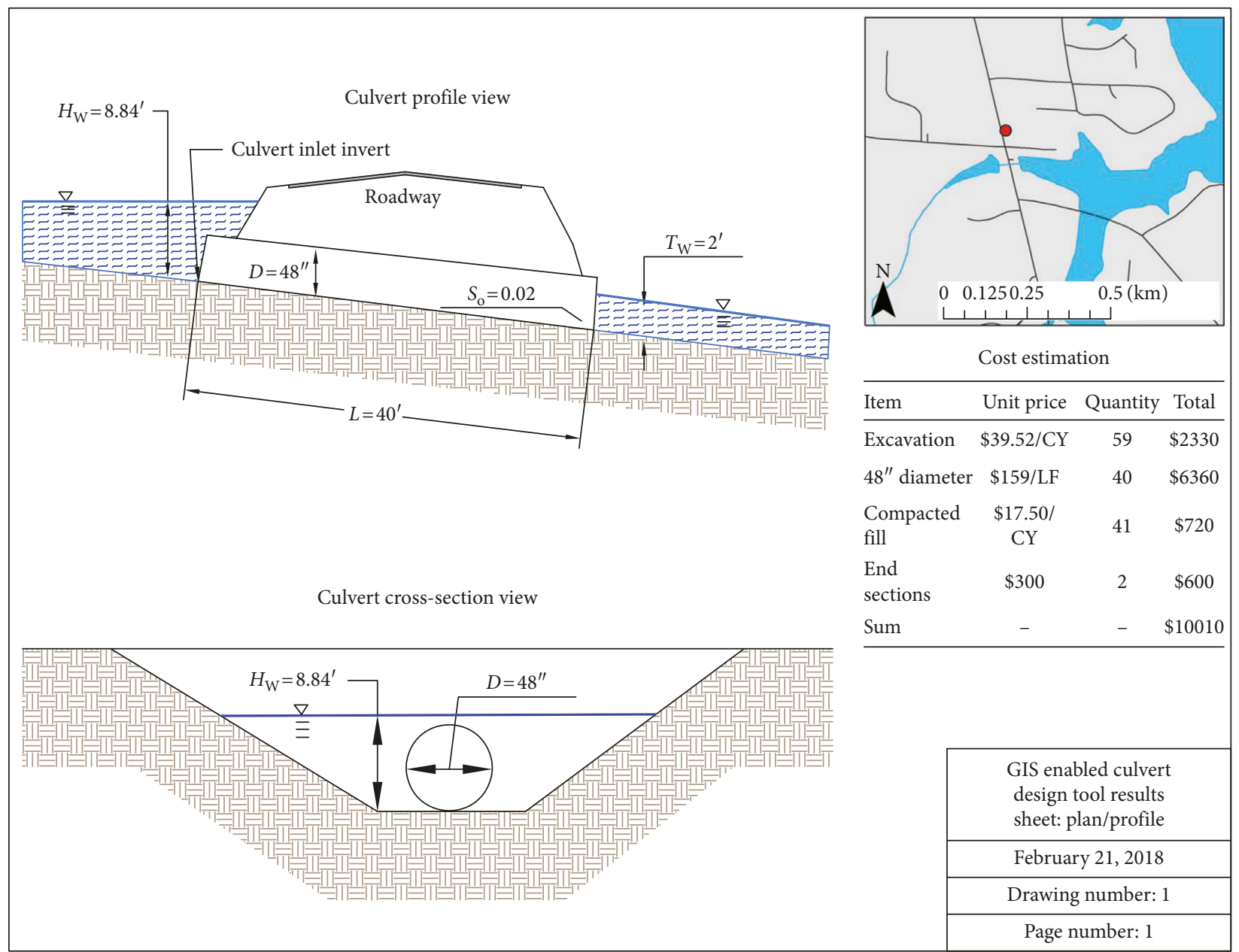

FIGURE 5: Sample output culvert design sheet.

both the hand-calculated procedure and the GIS-enabled automated approach. Table 3 shows the average flow difference between the two procedures was 3.4 percent. The differences in flow rate come from discrepancies in estimated spatial parameters compared to the same parameters obtained through a GIS analysis, which are likely more accurate.

In addition to verifying the results of the peak flow analysis for each watershed, the calculated culvert diameters were also validated. Through the GIS-enabled tool, culvert diameters were determined to accommodate the peak flows from each watershed. The same parameters were used as inputs to the FHWA's HY-8 software to verify that the calculated culvert diameters were suitable. Each of the HY-8calculated culvert diameters matches the diameter calculated through the GIS-enabled tool, as shown in Table 4.

These results provide assurance that the GIS-enabled culvert design tool is working properly. It should be noted that it takes approximately 30-60 minutes on average to calculate a design flowrate and design a culvert by hand, while the GIS-automated approach takes less than 2 minutes. This is a substantial average time savings of $95 \%$ that indicates the benefit of this GIS-enabled approach to hydraulic structure design.
2.4. Case Study. Ten circular concrete culverts along Alabama Highway 43 were chosen as a case study (Figure 6). Observed data such as material, inlet/outlet configuration, diameter, length, slope, and depth of cover were recorded. The culvert tool was used to redesign all ten culverts with existing length and slope as inputs. The culverts were all designed for a 25 -year design storm and an assumed tailwater value of $0.61 \mathrm{~m}(2 \mathrm{ft})$.

\section{Results and Discussion}

Design results were produced for the ten existing culvert locations, and the tool results were then compared to the existing culvert designs. The results are displayed in Table 5. The time required to produce the ten culvert designs was far less than it would have taken to design each of them by hand. Whereas a hand-calculated analysis would have taken close to an hour per culvert, the total analysis time for all ten culverts was less than half an hour.

In $100 \%$ of the trials, the resulting model diameters are larger than the existing culvert diameters. These results indicate that the existing culverts may be undersized. In order to convey flow from a 25-year rainfall event, the results show that the culvert diameters need to be anywhere from 
TABLE 3: Quality assurance and control results for three culvert drainage basins.

\begin{tabular}{lccccccccc}
\hline Culvert ID & $C$ & $\begin{array}{c}\text { Slope } \\
(\mathrm{m} / \mathrm{m})\end{array}$ & $\begin{array}{c}\text { Flow } \\
\text { length }(\mathrm{m})\end{array}$ & $T_{\mathrm{c}}(\mathrm{min})$ & $\begin{array}{c}i, 10 \text {-year event } \\
(\mathrm{mm} / \mathrm{hr})\end{array}$ & Area $\left(\mathrm{km}^{2}\right)$ & $Q_{\text {hand calc }}\left(\mathrm{m}^{3} / \mathrm{s}\right)$ & $Q_{\mathrm{GIS} \text {,auto }}\left(\mathrm{m}^{3} / \mathrm{s}\right)$ & $\begin{array}{c}\text { Percent } \\
\text { difference }(\%)\end{array}$ \\
\hline 1 & 0.30 & 0.03 & 1506 & 21.75 & 0.105 & 0.684 & 5.918 & 6.172 & 4.29 \\
2 & 0.32 & 0.05 & 747 & 9.91 & 0.159 & 0.215 & 3.003 & 2.837 & -5.53 \\
3 & 0.33 & 0.03 & 750 & 16.99 & 0.129 & 0.251 & 2.932 & 2.946 & 0.46 \\
& & & & & & & & Average \% difference & 3.4 \\
\hline
\end{tabular}

TABLE 4: Quality assurance for three culvert diameters.

\begin{tabular}{lccccccc}
\hline Culvert ID & $Q_{\text {GIS,auto }}\left(\mathrm{m}^{3} / \mathrm{s}\right)$ & Slope $(\mathrm{m} / \mathrm{m})$ & $\begin{array}{c}\text { Length, } \\
\mathrm{m}(\mathrm{ft})\end{array}$ & Headwater constraint, $(\mathrm{m})$ & Tailwater value (m) & $\begin{array}{c}D_{\mathrm{GIS}, \text { auto, }} \\
\mathrm{m}(\mathrm{ft})\end{array}$ & $\begin{array}{c}\text { HY-8 } \\
\text { verification }\end{array}$ \\
\hline 1 & 6.172 & 0.02 & $12.2(40)$ & 3.05 & 0.610 & $1.372(4.5)$ & $\checkmark$ \\
2 & 2.837 & 0.02 & $12.2(40)$ & 3.05 & 0.610 & $0.914(3.0)$ & $\checkmark$ \\
3 & 2.946 & 0.02 & $12.2(40)$ & 3.05 & 0.610 & $0.914(3.0)$ & $\checkmark$ \\
\hline
\end{tabular}

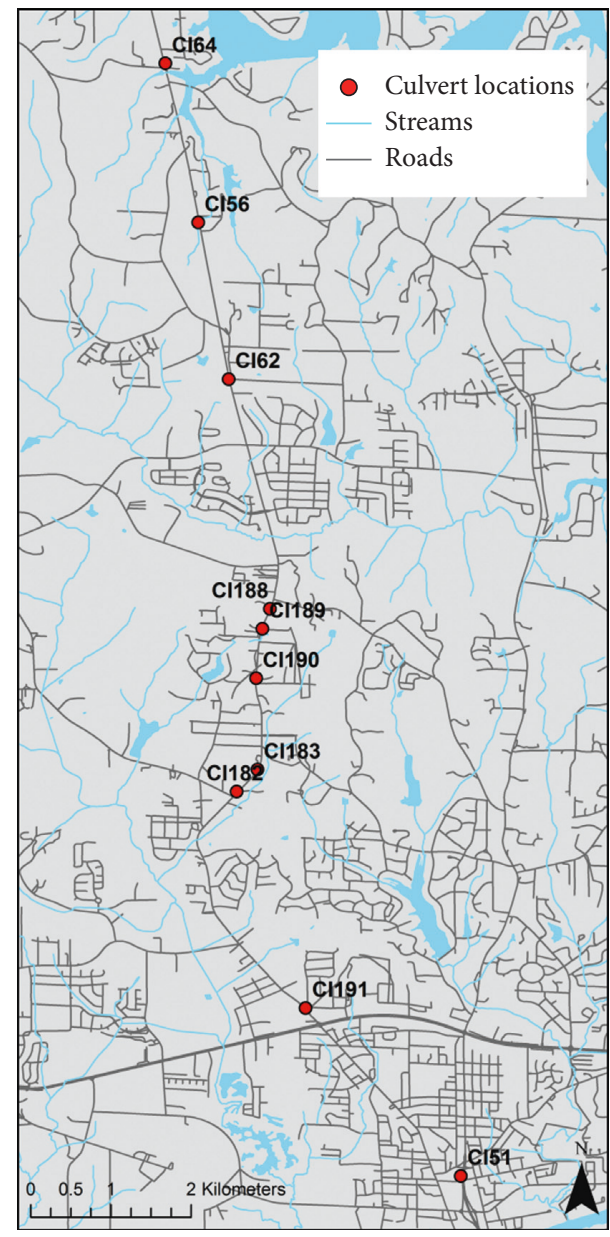

FIGURE 6: Map of study area including roadways, streams, and existing culvert locations.

0.15 to 0.76 meters ( 0.5 to 2.5 feet) larger. It is worthwhile to note that the tool iterates through a list of commercially available pipe diameters. Thus, if the tool determines that a pipe diameter is above a given threshold, it will automatically assign the next available pipe size to the culvert. This could potentially add 0.15 to 0.30 meters ( 0.5 to 1 foot) to the culvert diameter, adding to the discrepancy between model results and existing diameters.

It is possible that these results occur because the original culverts were designed when land cover conditions did not produce as much runoff or because rainfall intensities for certain design storms are now greater than they were when the culverts were designed. Factors such as assumption of design storm and tailwater values, variations in peak flow calculation approaches, and the presence of existing drainage infrastructure may have also contributed to these results. Nevertheless, there is a valuable time-savings benefit provided through the culvert design tool is valuable. This time saving will allow users to perform similar analyses for decision support purposes at various locations and scales.

\section{Conclusions}

The GIS-enabled culvert design tool presented herein allows a user to choose the geographic location of a proposed culvert and automatically design the culvert within a singlecomputational platform. The technique uses geographic input data from USGS digital elevation data and NLCD to determine the rational method runoff coefficient, to delineate the watershed, and to calculate the stream length and slope and time of concentration. From this information, the user is prompted for typical culvert design parameters such as pipe slope and length, headwater and tailwater depths, and the design storm year; the latter is used for retrieving rainfall data from NOAA. Given the input data and user input variables, the GIS-enabled culvert design tool progressively checks pipes against constraints from the smallest pipe to larger pipes until the smallest appropriate pipe diameter is found. The results of the automated tool was compared very well to results of traditional hand calculation, within 5 percent difference, and the results were produced at a fraction of the time, taking only 2 minutes to design a culvert using the GIS-enabled culvert design tool.

The tool was used to redesign culverts at ten locations within Tuscaloosa, Alabama, demonstrating that the existing culvert diameters may not be large enough to convey flows during a 25-year rainfall event. Though future work involves 
TABLE 5: Results of culvert designs for Tuscaloosa locations.

\begin{tabular}{lcccccc}
\hline Culvert ID & $C$ & $I(\mathrm{~mm} / \mathrm{hr})$ & $A\left(\mathrm{~m}^{2}\right)$ & $Q\left(\mathrm{~m}^{3} / \mathrm{s}\right)$ & Diameter $_{\text {model }}, \mathrm{m}(\mathrm{ft})$ & Diameter $_{\text {existing, }} \mathrm{m}(\mathrm{ft})$ \\
\hline CI51 & 0.8 & 0.183 & 0.125 & 5.31 & $1.219(4.0)$ & $0.457(1.5)$ \\
CI64 & 0.5 & 0.205 & 0.137 & 4.10 & $1.067(3.5)$ & $0.457(1.5)$ \\
CI190 & 0.6 & 0.226 & 0.059 & 2.08 & $0.762(2.5)$ & $0.614(3.0)$ \\
CI56 & 0.3 & 0.168 & 0.169 & 2.58 & $0.914(3.0)$ & $0.457(1.5)$ \\
CI62 & 0.7 & 0.213 & 0.067 & 2.69 & $1.067(3.5)$ & $0.610(2.0)$ \\
CI188 & 0.7 & 0.204 & 0.089 & 3.66 & $1.067(3.5)$ & $0.610(2.0)$ \\
CI189 & 0.5 & 0.169 & 0.136 & 3.44 & $0.610(2.0)$ & $0.610(2.0)$ \\
CI191 & 0.8 & 0.232 & 0.025 & 1.31 & $0.914(3.0)$ & $0.305(1.0)$ \\
CI183 & 0.8 & 0.218 & 0.065 & 3.05 & $0.762(2.5)$ & $0.457(1.5)$ \\
CI182 & 0.7 & 0.240 & 0.028 & 1.28 & & $0.457(1.5)$ \\
\hline
\end{tabular}

exploring the reasons behind these results, the results demonstrate the potential to use the GIS-based methods herein to identify vulnerabilities in existing highway drainage infrastructure.

Though there is a significant advantage to using the GISenabled culvert design tool in terms of time saving, the tool is currently only applicable to a singular culvert design shape, material, configuration, and flow type. To improve the functionality of the tool, additional design parameters will be added. The increasing availability of high-resolution elevation and land cover data will improve the accuracy of resulting designs. Additionally, future updates to the ArcGIS software will require that the tool be revised to ensure compatibility with current and future versions of the GIS platform. There are also occasional updates to the USGS 3DEP as well as the NLCD that may impact the use of the GIS-enabled culvert design tool. Future work involves developing a web-based version of this tool, so that it will be openly accessible without the expense of ArcGIS software. Other helpful additions to the tool could include compatibility with other web-based tools such as StreamStats. In short, the ever changing digital environment will require updates to the tool as well.

While the work herein focuses on the design of culverts using GIS technology, the overall practice of hydrology and hydraulic engineering can be improved by employing the versatility of automated-GIS techniques in design. The demonstrated GIS techniques may be extended to other hydrological objectives in which the rational method or similar runoff calculation methods are used, such as openchannel design and runoff mitigation designs like detention and retention ponds. For DOTs and municipalities who lack the resources to adequately maintain and analyze infrastructure performance, automated methods demonstrated herein have the potential to help these organizations efficiently analyze infrastructure and prioritize improvements. The ease of use and time savings achieved through these GIS techniques have the potential to transform design of infrastructure and analysis of infrastructure performance in the future.

\section{Data Availability}

Elevation data for this work are obtained from the United States Geological Survey (USGS) 3D Elevation Program (3DEP). Digital Elevation Models (DEMs) can be downloaded from the 3DEP at a variety of resolutions. The tool is compatible with different DEM resolutions, but finer resolution rasters will result in more accurate watershed delineation. The 3DEP can be found at https://nationalmap. gov/3DEP/. Land cover data can be obtained from the National Land Cover Database (NLCD) as a 30-meter resolution raster. The raster for the contiguous United States can be downloaded from the NLCD website, and the tool requires the raster to contain the geographic area including the desired culvert location. NLCD data can be found at https://www.mrlc.gov/.

\section{Disclosure}

This manuscript builds on an extended abstract presented at the Transportation Research Board (TRB) 2018 Annual Meeting: Greer, A. D., Wilbanks, Z. B., Clifton, L. D., Wilson, B., and Graettinger, A. J. (2018), "Geographic Information System Enabled Culvert Design: A Case Study in Tuscaloosa, Alabama” (No. 18-02985).

\section{Conflicts of Interest}

The authors declare that there are no conflicts of interest regarding the publication of this paper.

\section{Supplementary Materials}

Supplementary materials link to an alpha version of the tool, and a downloadable user guide can be found at http://www. gisresearch.ua.edu. A link to a web-based version of the tool will be available shortly. (Supplementary Materials)

\section{References}

[1] Federal Highway Administration, "Culvert management case studies: Vermont, Oregon, Ohio, and Los Angeles County," May 2017, https://www.fhwa.dot.gov/asset/pubs/hif14008. pdf.

[2] Federal Highway Administration, HY-8 7.50, Computer Software, Federal Highway Administration, Washington, DC, USA, 2016, https://www.fhwa.dot.gov/engineering/hydraulics/ software/hy8/.

[3] Bentley, CulvertMaster Computer Software, Bentley, Huntsville, AL, USA, 2016, https://www.bentley.com/en/products/ product-line/hydraulics-and-hydrology-software/culvertmaster. 
[4] H. Chanson, "Introducing originality and innovation in engineering teaching: the hydraulic design of culverts," European Journal of Engineering Education, vol. 25, no. 4, pp. 377-391, 2000.

[5] United States Department of Agriculture, WinTR-20 1.11.11 Computer Software, United States Department of Agriculture, Washington, DC, USA, 2016, http://www.nrcs.usda.gov/wps/ portal/nrcs/detailfull//?cid=stelprdb1042793.

[6] United States Army Corps of Engineers, Hydrologic Modeling System HEC-HMS 4.2 Computer Software, Hydrologic Engineering Center, Davis, CA, USA, 2016, http://www.hec. usace.army.mil/software/hec-hms/.

[7] E. M. Castrogiovanni, G. La Loggia, and L. V. Noto, "Design storm prediction and hydrologic modeling using a web-GIS approach on a free-software platform," Atmospheric Research, vol. 77, no. 1-4, pp. 367-377, 2005.

[8] F. N. Correia, F. C. Rego, M. D. G. Saraiva, and I. Ramos, "Coupling GIS with hydrologic and hydraulic flood modelling," Water Resources Management, vol. 12, no. 3, pp. 229249, 1998

[9] J. R. Frankenberger, E. S. Brooks, M. T. Walter, M. F. Walter, and T. S. Steenhuis, "A GIS-based variable source area hydrology model," Hydrological Processes, vol. 13, no. 6, pp. 805-822, 1999.

[10] D. Judi, A. Kalyanapu, S. Burian, S. Linger, A. Berscheid, and T. McPherson, "GIS-based prediction of hurricane flood inundation," in Proceedings of World Environmental and Water Resources Congress 2007, pp. 1-9, Tampa, FL, USA, May 2007.

[11] A. J. Kalyanapu, D. Judi, S. J. Burian, A. Berscheid, B. Hodge, and T. N. McPherson, "Channel morphology tool (CMT): a GIS-based automated extraction model for channel geometry," in Proceedings of World Environmental and Water Resources Congress 2007: Restoring our Natural Habitat, ASCE, Tampa, FL, USA, May 2007.

[12] B. A. DeVantier and A. D. Feldman, "Review of GIS applications in hydrologic modeling," Journal of Water Resources Planning and Management, vol. 119, no. 2, pp. 246-261, 1993.

[13] M. Günal, M. Ay, and A. Günal, "Cross-drainage culvert design by using GIS," Acta Physica Polonica A, vol. 132, no. 3, pp. 595-598, 2017.

[14] Environmental Systems Research Institute, ArcGIS 10.4 Computer Software, Environmental Systems Research Institute, Redlands, CA, USA, 2016, http://www.esri.com/ software/arcgis.

[15] Environmental Systems Research Institute, "What is a python add-in?," September 2016, http://desktop.arcgis.com/en/arcmap/ latest/analyze/python-addins/what-is-a-python-add-in.htm.

[16] United States Geological Survey, "13D elevation program (3DEP)," 2016, https://nationalmap.gov/3DEP/index.html.

[17] C. G. Homer, J. A. Dewitz, L. Yang et al., "Completion of the 2011 national land cover database for the conterminous United States-representing a decade of land cover change information," Photogrammetric Engineering and Remote Sensing, vol. 81, no. 5, pp. 345-354, 2015.

[18] K. G. Ries III, J. D. Guthrie, A. H. Rea, P. A. Steeves, and D. W. Stewart, StreamStats: A Water Resources Web Application. No. 2008-3067, US Geological Survey, Reston, VA, USA, 2008, https://water.usgs.gov/osw/streamstats/.

[19] W. J. Elliot, D. E. Hall, and P. R. Robichaud, Forest Service Peak Flow Calculator, Ver. 2015.04.05, U.S. Department of Agriculture, Forest Service, Rocky Mountain Research Station, Moscow, Russia, 2010, http://forest.moscowfsl.wsu.edu/ fswepp/ermit/peakflow.
[20] USDA, SCS, "Urban hydrology for small watersheds," Technical Release 55, USDA, SCS, Washington, DC, USA, 1986.

[21] E. Kuichling and R. Hering, The Relation Between the Rainfall and the Discharge of Sewers in Populous Districts, vol. 20 of Transactions, American Society of Civil Engineers, American Society of Civil Engineers, New York, NY, USA, pp. 1-56, 1889.

[22] C. B. Young, B. M. McEnroe, and A. C. Rome, "Empirical determination of rational method runoff coefficients," Journal of Hydrologic Engineering, vol. 14, no. 12, pp. 1283-1289, 2009.

[23] Z. Kirpich, "Time of concentration of small agricultural watersheds," Civil Engineering, vol. 10, no. 6, p. 362, 1940, The original source for the Kirpich equation. (In PDF).

[24] National Oceanic and Atmospheric Administration, Precipitation Frequency Data Server, National Oceanic and Atmospheric Administration, Silver Spring, MD, USA, 2017, http://hdsc.nws.noaa.gov/hdsc/pfds/.

[25] Federal Highway Administration, Hydraulic Design of Highway Culverts, Hydraulic Design Series Number 5, Federal Highway Administration, Washington, DC, USA, 3rd edition, August 2016, http://isddc.gov/OLPFiles/FHWA/015808.pdf. 


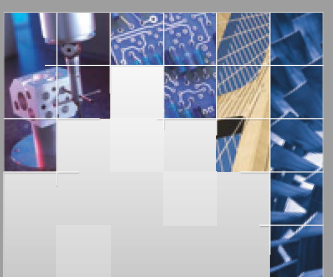

\section{Enfincering}
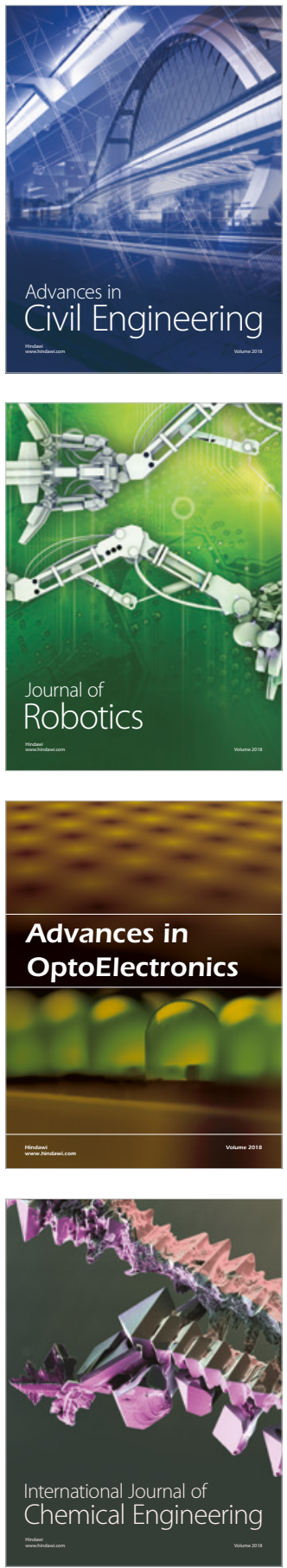

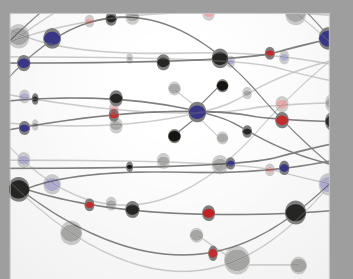

\section{Rotating \\ Machinery}

The Scientific World Journal

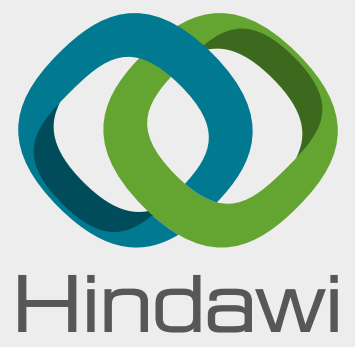

Submit your manuscripts at

www.hindawi.com
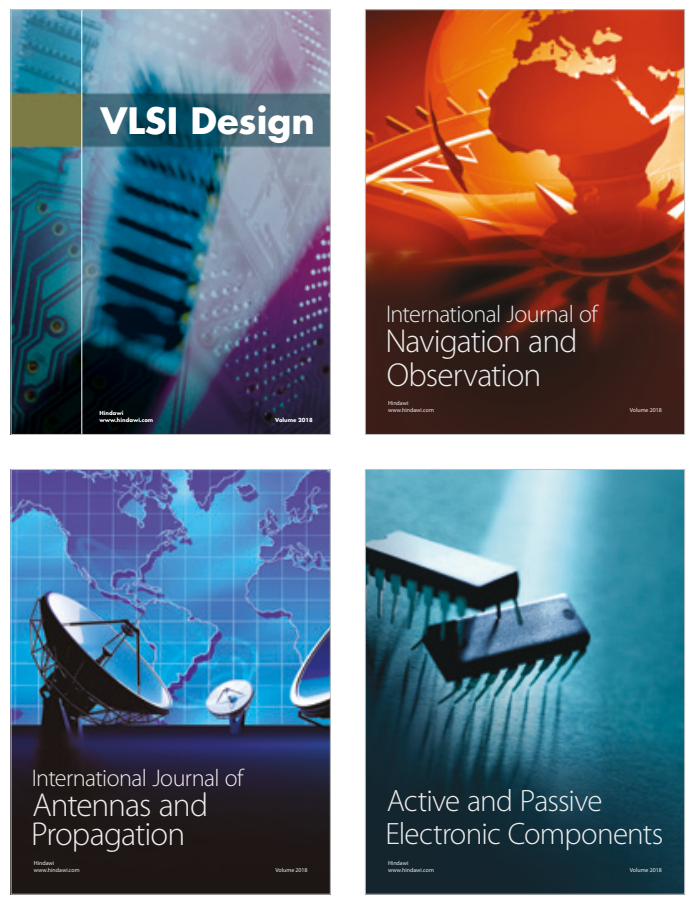
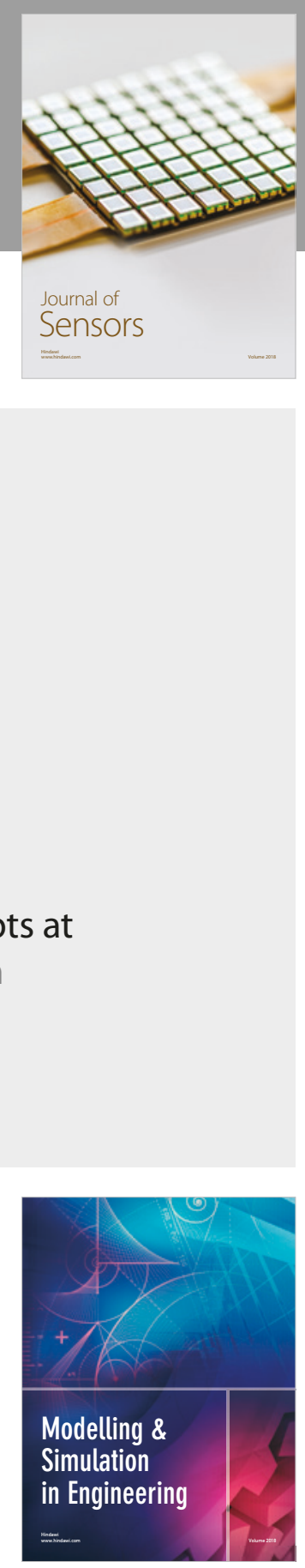

\section{Advances \\ Multimedia}
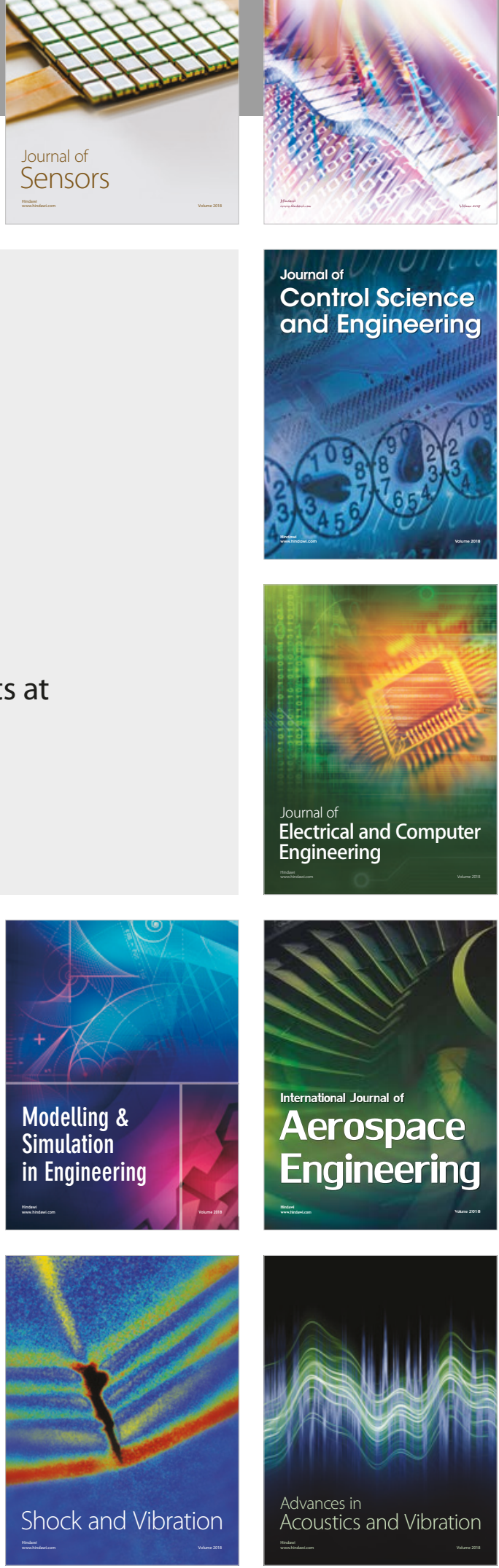